\title{
Effectiveness of the Metacognitive - Based Algebra Learning Model
}

\author{
Akhsanul In'am', Zulkifley Mohammad², Zeti Yusmira Jaludin ${ }^{3}$
}

\begin{abstract}
University of Muhammadiyah Malang, 246 Raya Tlogomas St. Malang, Indonesia, ahsanul_in@yahoo.com Sultan Idris Education University, 35900 Tanjong Malim, Perak Darul Ridzuan, Malaysia, zulkifley@fsmt.upsi.edu.my

Seri Begawan Religious Teachers' University College, 2 KM, Raja Isteri Pengiran Anak Saleha St., BA-2111Bandar, Seri Begawan, Brunei Darussalam, zetiyusmira@gmail.com
\end{abstract}

Annotation. Learning approaches are among the critical factors that determine learning effectiveness. A typical learning approach that promotes student awareness will result in successful learning. This article examines the effectiveness of a metacognitive-based algebra learning from three aspects, namely: 1) learning outcomes; 2) student responses; and 3) student activities in learning algebra. The results show that all three aspects meet the effectiveness criteria of metacognitive approach in learning algebra.

Keywords: effectiveness, learning result, metacognitive, students' response.

\section{Introduction}

Some researchers showed that mathematics is a subject with a high percentage of failure and the majority of the students' achievement is at the moderate stage (Bradshaw \& Hazell, 2017; Rebello et al., 2019). The research result is in line with the mathematics intellectuals' concern with the problems the students have in solving mathematical problems, but most educators realize that there are many students who have some difficulties in solving mathematical problems (Hacker et al., 2019; Sinaga et al., 2017). Solving mathematical problems is an abstract and complicated process that involves human's thinking and reasoning power (In'am, 2014).

Some problems encountered by students in solving mathematical problems are caused by their' low understanding of the problems to solve (Novak \& Tassell, 2017; Rebello et al., 2019; In'am, 2016). Such less understanding is due to some factors among others: 
low basis possessed by the students as the material to understand problems. Some other students, who can understand the problems, may make plans as their solution steps, but they possess less knowledge and skills in solving problems. Most problems, if considered from the process of solving them, lie at the aspects of the review of the obtained results (Lai et al., 2015; Phonapichat et al., 2014; Sakshaug \& Wohlhuter, 2010). Those with high capability do not make some reviews since they are sure that their solutions are correct. It is different from those with low and moderate capabilities. They also do not make reviews, since they do not have enough time to review their works.

Algebra is one of the studies in mathematics. Many studies showed that the difficulty in learning algebra is caused by the teaching of arithmetic which is more focused on the aspect of the process of algebra rather than the aspect of the structure. The learning of algebra is emphasized on the representation of symbols produced through generalization processes using a mathematical model (Sfard, 1995; Nurdin, 2007). Some studies that have been conducted in the field of algebra focusing on problem solving dealing with the strategies and concepts showed that the teachers could do the learning process more effectively in the classroom. Meanwhile, an aspect that should be given attention concerning the learning of algebra is the way the students think when they solve problems. It is needed to understand their mathematical thinking process.

Students' mathematical thinking process is a factor that is less paid attention to, but it plays a role which is very meaningful in solving mathematical problems. This mathematical thinking process is called metacognitive treatment (Topcu \& Ubuz, 2008). Therefore, the emphasis on the implementation of the mathematical learning focused on the students' thinking process should be given, and this can be conducted through metacognitive approach. This notion on metacognitive learning sparks an interest in the study of algebra, as the central topic of this present research (Jeni \& David, 2004; Richard, 1998; In'am, 2015). Realizing the importance of teachers and also the need for the metacognitive approach to the learning implementation, in this present research, the effectiveness of the metacognitive approach-based mathematics learning model would be examined

\section{Literature Review}

Learning mathematics at school is aimed at making students possess: 1) abilities that may be used in mathematical activities; 2) knowledge as their provisions to continue their study at higher levels; 3 ) mathematical skills to improve their mathematical mastery in elementary school for their daily life, and 4) good enough insights, and logical, critical, careful and discipline attitudes and high respect to the use of mathematics (Browning et al., 2014; In'am, 2014). Dealing with the curriculum, mathematics in secondary high school is aimed at creating students with systemized and logical thinking, and skills in 
making effective uses of mathematical knowledge and possessing responsibility in solving any problems in this information era.

The effort to attain the objective in teaching mathematics at school may be made through learning process that enables the students to reach their expectations. The implementation of learning mathematics is inseparable from psychological roles as an approach the teacher used to do his or her job. For teachers of mathematics, learning, understanding, and practicing learning psychology theories can improve their abilities and skills. There are two schools of learning psychology theories, namely behavioral and cognitive. Behavioral psychology combines teachers' knowledge to understand how students learn which is called learning psychology, and what should teachers do in conducting their teaching tasks as learning psychology. By combining the two theories, learning activities can reach the expected goals. An expert under behavioral psychology is Edward Thorndike who describes a learning law known as Law of Effect, stating that learning is the relationship formation between stimulus and response through reinforcement steps which are then accompanied with satisfaction feeling (Maulana, 2008)

Satisfaction may be obtained by students because of compliments or rewards for the success of their work they have completed and the satisfaction may lead to their next success. Meanwhile, B. F. Skinner presented that reinforcement plays an important role in the learning process, since it may improve students' behavior in doing their learning activities. The learning will be successful and students will have good knowledge if the learning is done meaningfully, meaning that the learning process should be done by not merely memorizing, but also looking for meanings in the subject learned. Meanwhile, Gagne stated that in learning mathematics, there are two objects the students get, a namely indirect object consisting among others: the ability to study and solve problems, self-learning, positive attitude towards mathematics, and knowing how to learn, and indirect objects including facts, skills, concepts, and rules (In'am, 2015).

The next is the cognitive psychology where the prominent figure among other is Jean Piaget. He stated that knowledge is obtained through information accepted and processed on the basis of the existing knowledge. As a result, in learning activities, two processes occur, namely the process of the information organization and adaptation. Therefore, when one accepts information, he will relate it to his existing knowledge structure stored in his mind. This is called an information organization process ( $\mathrm{Cu} \&$ Chien, 2017; Lee, 2018). Through this process, human beings may understand new information obtained by adapting the obtained knowledge to the knowledge structure possessed. Bruner in his theory states that learning mathematics may be successfull if a learning process leads to concepts and structures related to the topic disccused besides the relation between the concept and the concerned structure. Brownell stated that learning mathematics is a meaningful learning and it is a process of understanding. It is explicitly stated that learning in essence is a meaningful process. 
Besides viewing the learning process at school, it is also necessary to pay attention to the aspects of the learning approach which is the way a teacher does his activities with the objective that his students may understand the subject presented. In learning mathematics, there are two approaches: methodological and subject. A methodological approach deals with the way students conform concepts studied to their cognitive structure appropriate to the way the teacher conveys the materials. This approach is a way to be able to adapt and understand a concept, so that the approach may adjust to his existing knowledge. Whereas, a subject approach is the learning of mathematics which is based on the subject that has been possessed and understood by students. Some approaches included in the methodological group among others are intuitive, inductive, thematic, and realistic approaches (Nurdin, 2007). While a subject approach is exemplified as follows: for example, in conveying a subject of algebraic operation, students have understood and possessed knowledge of real numbers and various types of operation

\section{Method}

A quantitative approach with descriptive type was employed in this present research. This research was carried out in State Junior High School 10 Malang with the subject of Classes $8 \mathrm{G}$ and $8 \mathrm{H}$. Each class consisted of 38 students. The average score and standard deviation of the two studied classes were $48.55(\mathrm{SD}=8.52)$ for Class $\mathrm{G}$; and $51.71(\mathrm{SD}=8.34$ ) for Class $\mathrm{H}$. The minimum score of students' mathematical competency was 27.50 , and the maximum score was 65.0. This result informed researchers about students' mathematical competency. Accordingly, the given questions were in a high level of difficulty, in which using the students' score to mark their learning achievement was not recommended. These results were solely used to measure students' initial competency upon embarking on a new learning method.

\section{Table 1}

Score of Students' Mathematical Score in Class G and Class F

\begin{tabular}{ccccccc}
\hline Group & N & Min & SD & SE & Minimum Score & Maximum Score \\
\hline 1 (Class G) & 38 & 48.55 & 8.52 & 1.38 & 35.00 & 62.50 \\
2 (Class H) & 38 & 51.71 & 8.34 & 1.35 & 27.50 & 65.00 \\
\hline
\end{tabular}

Results from SPSS analysis showed a slight difference in students' mathematical competency by $0.422(r>0.05)$. It can be concluded that there was no significant difference between the two groups of studied classes.

The data were obtained through observations made by the teachers as the observers. They made the observations using the following instruments: 1) student's achievement; 
2) students' activities, and 3) students' responses to the model developed. The instrument of student's achievement was obtained through a series of material tests of algebra, while the instrument of learning activities consisted of eight items:1) listening and attending teachers' explanation; 2) reading the students' worksheets to find strategies in understanding the problems; 3) finding strategies to solve the problems; 4) asking questions, presenting idea, or asking explanations to the classmates or teachers; 5) giving responses to the teachers or giving assistances to the classmates; 6) correcting the works or writing something new from the results of the discussion; 7) making summary of how to understand or solve problems; and 8) doing activities out of the learning process, namely activities that were not related to the learning process, such as playing, and bothering the classmates.

The instrument of the students' responses consisted of three indicators: 1) interest consisting of 9 items; 2) novelty, 5 items; and 3) an easiness level with 6 items. To make the instrument may be used to take data, an instrument validity was made by asking two raters to review it to evaluate the adequacy of the instrument. A data analysis was established by paying attention to the criteria of effectiveness of the implementation of the learning process containing three aspects: 1) students' responses to the learning implementation; 2) students' activities in the learning implementation, and 3) learning results.

The data were collected through an instrument with a Likert scale, low (1), moderate (2), good (3); and very good (4). Questionnaires were administrated by two observers during the learning activities, while the learning results were obtained by testing the material of algebra after the learning process. The data were analyzed with percentage and calculation of the mean score from the collected instrument.

\section{Results}

On the basis of the data obtained from the instruments, three aspects were found to know the effectiveness of the learning process: 1) the achievement of the learning results; 2) students' activities; and 3) students' responses to the learning activities done. The experiments were conducted twice. The first experiment was carried out the subject of the students Class $8 \mathrm{G}$, the second experiment was made in class $8 \mathrm{H}$ in Junior High School 10 Malang. The results of the experiments are presented below.

\section{Students' Achievement}

Analysis of the students' achievement was made on their scores of the evaluation of their mastery of algebra. The analysis of the students' achievement was based on the achievement of individual and classical success. If a student obtains a score equivalent to or higher than 65 the concerned student reaches an individual success. While the classical success was based on the minimal achievement of $75 \%$ from the students reaching the 
minimum score of 65 . The aspects of students' achievement in the effectiveness of the model were evaluated based on classical success. On the basis of the results of the evaluation of the students' achievement in the experiment 1, it was known that the classical success was not reached yet. Therefore, it can be stated that the aspect of the students' achievement had not fulfilled the criteria of the model effectiveness. The results of the students' achievement evaluation are presented in Table 2.

\section{Table 2}

Results of the Evaluation of Students' Learning Achievement

\begin{tabular}{ccccc}
\hline No & $\begin{array}{c}\text { Results of Achievement } \\
\text { Evaluation }(x)\end{array}$ & 1st Experiment & 2nd Experiment & Criteria \\
\hline 1 & $x \geq 65$ & $20(52.63 \%)$ & $29(76.32 \%)$ & Successful \\
2 & $x<65$ & $18(47.37 \%)$ & $9(23.68 \%)$ & Unsuccessful \\
\hline
\end{tabular}

Table 2 shows that the results of the students' achievement evaluation on algebra in the first experiment are higher than 65 among 38 students or $56.63 \%$. It means that the effectiveness of the model viewed from the aspect of the achievement of the students' learning results is unsuccessful, since according to the criteria of the achievement evaluation, it is called to be successful if it is higher than 65 .

From Table 2, it is known that the number of students with learning achievement equivalent to or higher than 65 is 29 or $76.32 \%$. On the basis of the success criteria of the effectiveness of the model from the achievement aspect, it is determined that if $75 \%$ or more students reach the score of 65 , the model is effective viewed from the students' achievement. Therefore, it can be stated that from the students' achievement, the effectiveness of the model is good in the second experiment.

\section{Students' Activities}

Students' activities are a prerequisite understanding the effectiveness of the model in the learning implementation. The implementation of the learning activities and the expected activities standard may be made through the created model. The results of this research were obtained from the observations of the learning activities for six sessions. Two observers $\left(\mathrm{O}_{1}, \mathrm{O}_{2}\right)$ should finish the instruments of observation of six students taken from three groups of students where each group consisted of two students from high, moderate, and low abilities. The results of the students' activities are presented in Table 3.

On the basis of the data presented in Table 2, it is known that the percentage of the students' activities dealing with listening and attending the explanation from the teachers was $17.3 \%$ and the criteria of effectiveness of the students' activities for the aspect number 1 to 6 the percentage was $10 \%$ to $20 \%$. Therefore, it can be stated that the activity number 1 has fulfilled the criteria of effectiveness. The percentage of students' activities 
dealing with finding the strategy to understand the problems on the basis of the information obtained from observation was $10.5 \%$. It also happened to the activity number 3 concerning with the strategy to solve problems with the percentage of $13.6 \%$ where this strategy is out of the criteria standard. It means that this activity has not been able to be done in accordance with the criteria standard.

The student's activities dealing with conveying ideas, asking about the materials, responding to the explanation, assisting the classmates and improving the results of the works, including reviewing of the work can be stated to fulfill the standard of the criteria of students' activities in the learning activities. Making summaries to understand problems or the way to solve problems was not well done in the learning activities. This is shown in Table 2 that the percentage of this activity was $7.4 \%$ and it is out of the criteria standard of the effectiveness of students' activities.

\section{Table 3}

Students' Activities

\begin{tabular}{|c|c|c|c|c|}
\hline \multirow{2}{*}{ No } & \multirow{2}{*}{ Activity } & \multicolumn{2}{|c|}{ Mean } & \multirow{2}{*}{ Criteria } \\
\hline & & 1st Experiment & 2nd Experiment & \\
\hline 1. & $\begin{array}{l}\text { Listening and attending teachers' } \\
\text { explanation. }\end{array}$ & $17.3 \%$ & $18.2 \%$ & $10 \%-20 \%$ \\
\hline 2. & $\begin{array}{l}\text { Reading the students' worksheets to } \\
\text { find strategies in understanding the } \\
\text { problems. }\end{array}$ & $10.5 \%$ & $17.5 \%$ & $10 \%-20 \%$ \\
\hline 3. & Finding strategies to solve problems. & $13.6 \%$ & $19.6 \%$ & $10 \%-20 \%$ \\
\hline 4. & $\begin{array}{l}\text { Asking questions, presenting idea, or } \\
\text { asking explanations to the classmates } \\
\text { or teachers. }\end{array}$ & $18.3 \%$ & $18.7 \%$ & $10 \%-20 \%$ \\
\hline 5. & $\begin{array}{l}\text { Giving responses to the teacher or giving } \\
\text { assistances to the classmates. }\end{array}$ & $17.2 \%$ & $17.6 \%$ & $10 \%-20 \%$ \\
\hline 6. & $\begin{array}{l}\text { Correcting the works or writing some- } \\
\text { thing new from the results of the dis- } \\
\text { cussion. }\end{array}$ & $16.4 \%$ & $19.2 \%$ & $10 \%-20 \%$ \\
\hline 7. & $\begin{array}{l}\text { Making summary of how to understand } \\
\text { or solve problems. }\end{array}$ & $7.4 \%$ & $13.5 \%$ & $5 \%-15 \%$ \\
\hline 8. & $\begin{array}{l}\text { Doing activities out of the learning } \\
\text { process, namely activities that were not } \\
\text { related to the learning process, such as } \\
\text { playing, bothering the classmates. }\end{array}$ & $7.2 \%$ & $3.1 \%$ & $0 \%-5 \%$ \\
\hline
\end{tabular}




\section{Students' Responses the Learning Process}

Students' responses are very meaningful to know whether the developed model may be successful or not, and it is one of the ways to know the effectiveness of the model. In this study, students' responses to the learning process were obtained from the instruments the students completed after they followed the learning activities using the developed model. The instrument of the students' responses consisted of three indicators namely interest, up to-date, and easiness level. The whole items of the instrument consisted of 20 items where 9 items for the interest indicator, 5 items for the up-to-date indicator, and 6 items for the easiness level.

Students' Responses to the Learning Process for Indicator of Interest

Table 4

Students' Responses to the Learning Process for the Interest Indicator

\begin{tabular}{|c|c|c|c|}
\hline \multirow{2}{*}{ No } & \multirow{2}{*}{ Item } & \multicolumn{2}{|c|}{ Mean } \\
\hline & & 1st Experiment & 2nd Experiment \\
\hline 1. & Subject & 3.53 & 3.61 \\
\hline 2. & Students' Book & 3.26 & 3.50 \\
\hline 3. & Language in Students' book & 3.39 & 3.61 \\
\hline 4. & Pictures in Students' book & 3.42 & 3.53 \\
\hline 5. & Students' Worksheets & 3.32 & 3.37 \\
\hline 6. & Language in the Students' Worksheets & 3.37 & 3.53 \\
\hline 7. & The Implementation of discussion & 3.47 & 3.63 \\
\hline 8. & $\begin{array}{l}\text { The way teachers implemented the learning } \\
\text { activities }\end{array}$ & 3.59 & 3.47 \\
\hline 9. & The implementation of the learning process & 3.47 & 3.50 \\
\hline 10. & Mean & 3.42 & 3.53 \\
\hline
\end{tabular}

The mean score in Table 4 is obtained from the two observers doing their tasks during the experiment. The results from the two observers who had given scores consisting of four Likert scale scores were then averaged. On the basis of Table 4, it is informed that as a whole students' responses to the learning process for the interest indicators, there is an increase in scores viewed from the 1st and 2 nd experiments. In the 1st experiment, the mean score from the nine aspects was 3.42 and in the 2 nd experiment, it increased into 3.53., but if it is considered from each item, there was one item that decreases in the mean score, from 3.59 in the 1st experiment into 3.47 in the 2 nd experiment, and it is in line with the item no.8, the way teachers implemented the learning activities.

For the mean score in the 1st experiment, there were four items under the low mean score namely items no. 2, 3, 5, 6 which as a whole deal with Language and students' worksheets. Concerning the picture in the worksheets, they had the mean score equivalent 
to the whole score. However, there were some items above the mean score as a whole, namely items no. 1, 7, 8, and 9. In general, it can be stated that students' responses to the learning process for the interest indicator showed this aspect as one of the ones meeting the criteria to show that the metacognitive-based algebra learning model is effective.

Students' Responses to the Learning Process for the up-to-date Indicators

As presented in Table 3, the mean score from eachitem is obtained from the average calculation from two observers making observations during the tryout of the model. On the basis of Table 4, it is known that the aspects of Students' Responses to the Learning Process for of up to-date Indicator consisted of five items with mean score in of 3.48 in the 1st Experiment and it increased into 3.54 in the second experiment. In the 1stexperiment, there was one item with under average score namely 3.26 which is in accordance with item no. 4 dealing with discussion activities, while in the 2nd Experiment there were three items under the average namely item no. 1 which deals with the presentation of the subject, item no. 2 concerning with students' book, and item on the discussion activities for item no. As one of the determinants of the effectiveness of a model, this part also fulfilled the criteria, as shown by the mean score from the first tryout to the second one with an increase of 0.06 .

\section{Table 5}

Students' Responses to the Learning Indicator

\begin{tabular}{llcc}
\hline \multirow{2}{*}{ No } & \multicolumn{1}{c}{ Item } & \multicolumn{2}{c}{ Mean } \\
\cline { 3 - 4 } & & 1st Experiment & 2nd Experiment \\
\hline 1. & Presentation of the Subject & 3.50 & 3.53 \\
2. Students' Book & 3.50 & 3.47 \\
3. Students' Worksheets & 3.26 & 3.63 \\
4. Activities of the Discussion & 3.53 & 3.53 \\
5. The way the teachers implemented the learning & & 3.55 \\
& activities & 3.48 & 3.54 \\
\hline
\end{tabular}

Students' Responses to the Learning Process for Indicators of Easiness Level

As shown in Tables 4 and 5, the mean score in the first and second experiments is the average calculation from the two observers who carried out their tasks by completing scores for each item consisting of four categories using a Likert scale of 1, 2, 3, and 4. On the basis of Table 5 , it was revealed that the average score from the two tryouts increase of 0.60 , meaning that the aspects of students' responses to the learning indicators of easiness level consisting of six items showed that the developed model has fulfilled the rule of model effectiveness. 
However, items of aspects occurring for each experiment may be analyzed. In the 1st experiment, it is known that there were four items under the average, namely item no. $1,2,3$, and 4 . Item no 5. Dealing with the Implementation of the discussion activities and item no 6 concerning the way teachers give instructions in the learning activities were above the average score in the 1st experiment. Compared with the 2nd experiment, there was one item experiencing a decrease in its score namely item no. 5, while other items increased in scores. In the 2 nd experiment, there was one item above the average score namely item no. 1 related to language in the book, while other items were under the average score.

\section{Table 6}

Students' Responses to the Learning Indicators of Easiness Level

\begin{tabular}{llcc}
\hline \multirow{2}{*}{ No } & \multicolumn{1}{c}{ Item } & \multicolumn{2}{c}{ Mean } \\
\cline { 3 - 4 } & & 1st Experiment & 2nd Experiment \\
\hline 1. & Language in the book & 3.45 & 3.76 \\
2. & Understanding pictures in the book & 3.47 & 3.50 \\
3. & Exercises in the book & 3.42 & 3.45 \\
4. & Exercises in the Students' Worksheets & 3.58 & 3.53 \\
5. Implementation of the discussion activities & 3.63 & 3.53 \\
6. The way teachers give instructions in the learning & & 3.50 \\
& activities & 3.49 & 3.55 \\
\hline
\end{tabular}

On the basis of Tables 4, 5, and 6, it was revealed that the aspects of students' responses to the learning process for the interest indicator had the mean score which increased from the 1 st to the 2 nd experiments with the mean score of 3.42 into 3.53 where the increase is 0.06 . the aspect of students' responses to the learning indicators of easiness level had the mean score of 3.49 in the 1st experiment and it increases of 0.06 , so that the whole average score in the 2 nd experiment was 3.55. The increase in the three aspects shows that the aspect of Students' responses indicates that the metacognitive-based algebra learning model is effective.

\section{Discussion}

The result shows that the metacognitive-based algebra learning model is effective for senior high schools. This result is in line with the research result carried out by Maulana (2008) that a metacognitive model is one of the alternatives that may be used to improve thinking ability in learning mathematics. Nurdin (2007), and Amin \& Mariani (2017) also 
found that learning mathematics may grow students' cognitive ability, but this research was carried out in senior high school. Research result from Temur et al. (2019) showed teachers should possess the ability to implement mathematics learning since this may improve the quality of mathematics learning. Moreover, Alzahrani (2017) found that learning mathematics based on cognitive should be well planned, where the strategy should be directly targeted to improve monitoring and regulating students' thinking in solving mathematical problems.

This is in accordance with the research result of Sinaga et al. (2017) in their research in State Senior High School 3 Gunungsitoli showing that learning mathematics based on a metacognitive strategy could improve problem-solving ability. The experiment carried out during the research revealed that there was some increase in ability in solving mathematical problems through learning based on metacognitive strategy.

While Sa'diyah (2006) in her research on model development referring to constructivism showed that this model may help improve students' achievement. One of the aspects of Constructivism is critical thinking ability and is one of the aspects in the metacognitive approach (Ahmad et al., 2018; Hightower, 2018). This research result also reinforces a point of view that a metacognitive approach may improve problem - solving ability (Fortunato et al., 1991; Xiaodong, 2001).

\section{Conclusion}

Concerning the data presentation related to the three aspects analysed, it is shown that the three aspects namely: 1) students' learning achievement in algebra;2) students' activities in implementing the learning of algebra; and 3) students' responses to algebra learning models based on metacognitive approaches are ineffective in the first experiment, because the learning results do not fulfil the determined criteria and some activities are out of the expected interval. But, in the second experiment, the three aspects fulfil the determined criteria. Therefore, the end results in the second experiment show that the learning algebra model base on metacognitive approach is effective.

\section{References}

Ahmad, H., Febryanti, F., \& Muthmainnah (2018). Description of student's metacognitive ability in understanding and solving mathematics problem. IOP Conference Series: Materials Science and Engineering, 300 (1), 1-7. https://doi.org/10.1088/1757-899X/300/1/012048

Alzahrani, K. S. (2017). Metacognition and its role in mathematics learning: an exploration of the perceptions of a teacher and students in a secondary school. International Electronic Journal of Mathematics Education, 12(3), 521-537. 
Amin, I., \& Mariani, S. (2017). PME learning model : The conceptual theoretical study of metacognition learning in mathematics problem solving based on constructivism. Iejme, $12(3), 333-352$.

Bradshaw, Z., \& Hazell, A. (2017). Developing problem-solving skills in mathematics: a lesson study. International Journal for Lesson and Learning Studies, 6(1), 32-44. https://doi. org/10.1108/IJLLS-09-2016-0032

Browning, A. J., Edson, \& Browning, C. (2014). Mathematical content knowledge for teaching elementary mathematics: A focus on geometry and measurement. The Mathematics Enthusiast, 11(2), 333-383.

Cu, P.-Y., \& Chien, Y.-H. (2017). The effectiveness of using stereoscopic 3D for proportion estimation in product design education. EURASIA Journal of Mathematics Science and Technology Education, 13(10), 6635-6648.

Fortunato, I., Hecht, D., Tittle, C., \& Alvarez, L. (1991). Metacognition and problem solving. Arithmetic Teacher, 39(4), 38-40.

Hacker, D. J., Kiuhara, S. A., \& Levin, J. R. (2019). A metacognitive intervention for teaching fractions to students with or at-risk for learning disabilities in mathematics. ZDM Mathematics Education, 51(4), 601-612. https://oi.org/10.1007/s11858-019-01040-0

Hightower, R. W. (2018). Teaching both cognitive and metacognitive skills for mathematics literacy: A case study of elementary school students with disabilities in Florida [Doctoral dissertation, Grand Canyon University]. ProQuest Dissertations and Theses.

In'am, A. (2014). The implementation of the Polya method in solving Euclidean geometry problems. International Education Studies, 7(7), 149-158. https://doi.org/10.5539/ies.v7n7p149

In'am, A. (2015). Menguak penyelesaian masalah matematika (Analisis pendekatan metakognitif dan model polya)[Revealing solving mathematical problems (Analysis of the metacognitive approach and its pattern of models)]. Jogjakarta: Aditya Media.

In'am, A. (2016). A logical thinking analysis through the Euclidean geometry. IEJME- Mathematics Education the Mathematics Enthusiast, 11(4), 961-974.

Jeni, W., \& David, C. (2004). Towards the modelling of mathematical metacognition. Mathematics Education Research Journal, 16(2), 25-48.

Lai, Y., Zhu, X., Chen, Y., \& Li, Y. (2015). Effects of mathematics anxiety and mathematical metacognition on word problem solving in children with and without mathematical learning difficulties, PLoS ONE, 10(6), e0130570.https://doi.org/10.1371/journal.pone.0130570

Lee, M. Y. (2018). Further investigation into the quality of teachers' noticing expertise: A proposed framework for evaluating teachers' models of students' mathematical thinking. EURASIA Journal of Mathematics Science and Technology Education, 14(11), 1-15.

Maulana (2008). Pendekatan Metakognitif sebagai Alternatif Pembelajaran Matematika untuk Meningkatkan Kemampuan Berpikir Kritis Mahasiswa PGSD [Metacognitive approach as an alternative for learning mathematics to improve the critical thinking ability of PGSD students] Bandung: Tesis Indonesian Education University. 
Novak, E., \& Tassell, J. L. (2017). Studying preservice teacher math anxiety and mathematics performance in geometry, word, and non-word problem solving. Learning and Individual Differences, 54, 20-29. https://doi.org/10.1016/j.lindif.2017.01.005

Nurdin (2007). Model Pembelajaran Matematika untuk Menumbuhkan Kemampuan Metakognitif. [Mathematics learning to develop metacognitive abilities] [Doctoral dissertation, Surabaya State University].

Phonapichat, P., Wongwanich, S., \& Sujiva, S. (2014). An analysis of elementary school students' difficulties in mathematical problem solving. Procedia - Social and Behavioral Sciences, 116, 3169-3174. https://doi.org/10.1016/j.sbspro.2014.01.728

Rebello, N. S., Cui, L., Bennett, A. G., Zollman, D. A., \& Ozimek, D. J. (2019). Transfer of learning in problem solving in the context of mathematics and physics. Learning to Solve Complex Scientific Problems, 223-246. https://doi.org/10.4324/9781315091938-10

Richard, E. M. (1998). Cognitive, metacognitive, and motivational aspects of problem-solving. Instructional Science, 26, 49-63.

Sa'diyah, C. (2006). Pengembangan Model Pembelajaran Matematika beracuan Konstruktivisme untuk Siswa SMP [Development of a mathematics earning model based on constructivism for junior high school students]. [Doctoral dissertation, Surabaya State University].

Sakshaug, L. E., \& Wohlhuter, K. A. (2010). Journey toward teaching mathematics through problem solving. School Science and Mathematics, 110(8), 397-409. https://doi.org/10.1111/j.19498594.2010.00051.x

Sfard, A. (1995). The development of algebra, confronting historical and psychological erspectives. Journal of Mathematics Behaviour, 14(1), 15-39.

Sinaga, Y. N. T. B., Mukhtar, \& Surya, E. (2017). Development of mathematics module based on metacognitive strategy in improving students' mathematical problem solving ability at high school. Journal of Education and Practice, 8(19), 73-80.

Temur, Ö. D., Özsoy, G., \& Turgut, S. (2019). Metacognitive instructional behaviours of preschool teachers in mathematical activities. ZDM - Mathematics Education, 1-12. https:/doi. org/10.1007/s11858-019-01069-1

Topcu, A., \& Ubuz, B. (2008). The effects of metacognitive knowledge on the pre-service teachers' participation in the asynchronous online forum. Online Forum. Educational Technology \& Society, 11(3), 1-12.

Xiaodong, L. (2001). Designing metacognitive activities. Education, Research, Technology and Development, 49(2), 23-40. 


\title{
Metakognityvinio algebros mokymosi modelio veiksmingumas
}

\author{
Akhsanul In'am ${ }^{1}$, Zulkifley Mohammad ${ }^{2}$, Zeti Yusmira Jaludin ${ }^{3}$ \\ 1 Muhammadiyah Malango universitetas, Raya Tlogomas 246, Malangas, Indonezija, ahsanul_in@yahoo.com \\ 2 Sultono Idris universitetas, Tanjong Malim 35900, Perak Darul Ridzuan, Malaizija, zulkifley@fsmt.upsi.edu.my \\ 3 Begavano religijos mokytojų universiteto kolegija, KM 2, Jalan Raja Isteri Pengiran Anak Saleha, BA-2111, Bandar \\ Seri Begavanas, Brunejaus Darusalamas, zetiyusmira@gmail.com
}

\section{Santrauka}

Metakognityvinė prieiga siejama su mokymosi sąmoningumu. Tokiu atveju mokiniai turi galimybę su mokytojais išsiaiškinti nesuprantamą mokymosi medžiagą. Vidurinėje mokykloje buvo atliktas klasès veiklos tyrimas dviem ciklais su dviejų 8 klasių mokiniais, kurie mokèsi metakognityvinès algebros. Kiekvienoje klasėje buvo po 38 mokinius. Metakognityvinès prieigos veiksmingumas mokantis algebros buvo tiriamas trimis aspektais: 1) mokinių mokymosi pasiekimai algebroje; 2) mokinių veikla mokantis algebros ir 3) mokinių atsakymai apie metakognityvinius algebros mokymosi modelius. Pirmojo ciklo rezultatai parodé, kad mokinių mokymosi rezultatai neatitiko nurodytų kriterijų, tačiau kai kurios veiklos buvo arti numatytų intervalų, o kiti du aspektai atitiko nurodytus kriterijus. Antrojo ciklo rezultatai parodé, kad trys pastebėti aspektai atitiko nurodytus kriterijus. Galima daryti išvadą, kad metakognityvinis algebros mokymasis buvo veiksmingas. Šis tyrimas rodo, kad metakognityvinis metodas gali tikti ir kitai mokymosi medžiagai, ne tik algebrai.

Esminiai žodžiai: veiksmingumas, mokymosi rezultatai, metakognityvinis, mokinių atsakymai.

Gauta 20200415 / Received 15042020

Priimta 20210219 / Accepted 19022021 